\title{
AS VOZES DAS CRIANÇAS E EXPERIÊNCIAS INSTITUINTES NA EDUCAÇÃO ANTIRRACISTA
}

\section{CHILDREN'S VOICES AND INSTITUTING EXPERIENCES IN ANTI-RACIST EDUCATION}

\author{
Daise dos Santos Pereira ${ }^{64}$ \\ Kirce Correa Bermute ${ }^{65}$
}

\section{Resumo}

O artigo apresenta experiências escolares, a partir da lei federal 10.639/03, percebida por nós como marcos de experiências instituintes. O público-alvo foi de crianças do Ensino Fundamental I de uma escola no município de Magé-RJ. A construção do texto buscou alicerçar-se na contribuição analítica de Frantz Fanon que compreendeu a libertação das mentes pela luta de ideias e prática. Os Projetos de trabalho foram caminhos metodológicos, envolvendo registros em caderno de campo e autobiográficos pelas crianças. A Sociologia da Infância, contribui para o corpo teórico-metodológico com as categorias: Reprodução Interpretativa e Etnografia Longitudinal. E reconhecendo que as crianças são ativas e inventivas, Michel de Certeau é chamado para a conversa, revelando suas 'Artes de Fazer'.

Palavras-chave: Vozes das crianças. Experiências instituintes. Artes de fazer. Educação antirracista. Sociologia da infância.

\begin{abstract}
The article presents school experiences, from the federal law 10.639/03, perceived by us as milestones of instituting experiences. The target audience was for elementary school children from a school in the municipality of Magé-RJ. The construction of the text sought to be based on the analytical contribution of Frantz Fanon, who understood the liberation of minds through the struggle of ideas and practice. The work projects were methodological paths, involving field notebook and autobiographical records by the children. The Sociology of Childhood, contributes to the theoretical-methodological body with the categories: Interpretative Reproduction and Longitudinal Ethnography. And recognizing that children are active and inventive, Michel de Certeau is called into the conversation, revealing his 'Arts of Making'.
\end{abstract}

Keywords: Children's voices. Instituting experiences. Arts of making. Anti-racist education. Childhood sociology.

\footnotetext{
64 Mestra em Diversidade e Inclusão (CMPDI) pela Universidade Federal Fluminense - Niterói/Brasil (2016). Especializada em Ensino de História e Ciências Sociais (UFF), Graduada em Pedagogia (UFF). Professora do Ensino Fundamental I na Prefeitura Municipal de Magé e Petrópolis. E-mail: daise2009@gmail.com / https://orcid.org/0000-0001-7743-4171

65 Graduação em Filosofia pela Universidade Federal do Rio de Janeiro (2018). Professora concursada do Ensino Fundamental I na Prefeitura Municipal de Magé. E-mail: kircebermute@gmail.com / https://orcid.org/00000002-9101-615X
} 
'Tia, se a gente pintar de preto, a cor que eu sou, todo mundo vai achar feio.'

(Narrativa infantil ${ }^{66}$ - autor: Bruno C.)

Há algum tempo, descobrimos o intelectual, militante político e anticolonialista francês Frantz Omar Fanon (1983). Acreditamos que ao falar sobre representatividade negra e construção de novas subjetividades no campo educacional, torna-se imprescindível diálogos com autores que buscaram interpretar as relações étnico-raciais de maneira crítica e reflexiva.

Assim, iniciamos esse texto chamando para a conversa um filósofo, que em seu tempo, lutou pela libertação das mentes, deixou um legado político na luta pela descolonização de países do terceiro mundo, além de obras ${ }^{67}$ que potencializam as reflexões contemporâneas sobre caminhos possíveis para a superação do racismo.

Também abrimos essa reflexão com uma epígrafe, que revela uma narrativa infantil do cotidiano escolar. A escolha por evidenciar a voz infantil, ocorre por entendermos que a criança é um ator social no processo educativo e grande aliada na compreensão das relações mais complexas da sociedade. Tais argumentos, se estruturam na Sociologia da Infância (CORSARO, 2005; SARMENTO, 2005, 2011), enquanto constructo epistemológico, que legitima a criança como produtora de cultura e reveladora das possibilidades da estrutura social (SARMENTO, 2005, p. 363). Nesse sentido, defendemos que: uma prática docente comprometida com a diversidade, com a escuta e a problematização das narrativas infantis expressadas no dia a dia, estará mais sensível a perceber os indícios que torna obrigatório o ensino das questões étnico-raciais desde a mais tenra idade (PEREIRA, 2018). A seguir, um registro que contextualiza a voz que abre esse texto, a partir de uma narrativa docente:

No primeiro dia de aula do ano letivo de 2019, distribuí para o 4으 ano um desenho para colorir que representava algumas crianças chegando na escola também em seu primeiro dia de aula. Após uns dez minutos, percebi que um grupo de crianças discutiam para ver quem pegava o "lápis cor de pele" primeiro. Este, tratava-se de um lápis rosa, bem claro. Então, eu fui até a

\footnotetext{
${ }^{66}$ Para Kramer (2002, p. 53), autoria se relaciona à autorização, à autoridade e à autonomia. Nesse sentido, as narrativas e imagens infantis presentes no texto, estão autorizadas pelas crianças e seus responsáveis.

67 Segundo Costa (2016), Frantz Fanon (1925-1961) escreveu apenas três livros: Peau noir, masques blancs (1952), L'an cinq de la Révolution Algérienne (1959) e Les damnés de la terre (1961). Mas a obra Pele Negra, Máscaras Brancas (1952) é a que dialoga intimamente com este trabalho. Você entenderá o porquê.
} 
frente da sala e bastante incomodada com a discussão, perguntei: 'Por que essa cor é cor de pele? É cor da pele de quem?’ Várias foram as respostas, mas a resposta que mais me causou desconforto, foi a de um aluno que respondeu: 'Tia, se a gente pintar de preto, a cor que eu sou, todo mundo vai achar feio.' Mesmo depois de uma longa explicação sobre o belo, e o que deve ser considerado belo, fiquei incomodada e percebi que a problemática em questão deveria ser muito mais explorada, mais discutida, pois, a resposta do pequeno, era somente uma camada superficial de uma questão muito mais complexa: a falta de representatividade negra dentro da escola e da comunidade (Registro do caderno de campo. BERMUTE, $2019^{68}$ ).

A cena evidencia narrativas comuns e emblemáticas do cotidiano de muitos professores e escolas. Não obstante, embora sejam recorrentes, a sua problematização, em prol de processos educativos que positivem as relações étnico-raciais, ainda faz parte de silêncios e invisibilidades.

Narrativas, cotidiano, invisibilidades e silêncios, nos remetem, inicialmente a dois autores que nos são caros e acreditamos que podem potencializar as redes reflexivas para a construção de uma educação antirracista.

Frantz Fanon, com a sua prece "Oh, meu corpo, faça sempre de mim um homem que questiona!", evidencia a importância da fala, bem como da problematização do lugar do sujeito colonizado. Nesse sentido, defendeu que a libertação das mentes só poderia ocorrer a partir da desconstrução de práticas discursivas, impactando a construção de outras/novas subjetividades (PEREIRA, 2020). Para sair da invisibilidade e do sentimento do não-ser, o silêncio não cabia. E o caminho para tal, era, senão, por meio de uma luta de ideias, luta prática e de reinvenção.

O segundo autor, nos remete ao cotidiano e às narrativas comuns dos sujeitos. Michel de Certeau ${ }^{69}$, historiador francês, conhecido por seus estudos sobre práticas culturais para a compreensão das práticas cotidianas, dizia que: o cotidiano é aquilo que nos é dado a cada dia (ou que nos cabe em partilha), nos pressiona dia após dia, nos oprime [...] O cotidiano é aquilo que nos prende intimamente, a partir do interior (CERTEAU, 1996, p. 36). E continua, afirmando que, o que interessa ao historiador do cotidiano é o invisível.

\footnotetext{
${ }^{68}$ A professora Kirce Bermute é uma das autoras deste artigo.

${ }^{69}$ Certeau nasceu na França em 1925. Foi um autor que buscou na interdisciplinaridade um modo de ser e fazer. Por isso, seus caminhos de formação são múltiplos, como: filosofia, letras clássicas, história e teologia. Foi um jesuíta (Companhia de Jesus-1950) e conciliou a vida religiosa com a vida de pesquisador. Lecionou em Paris na Ecole des Hautes Etudes em Sciences Sociales e na Universidade da Califórnia.
} 


\section{RevistAleph}

Assim, parafraseando Certeau, asseguramos que enquanto professoras que refletem sobre/com o cotidiano e militantes de educação antirracista, o que nos interessa são as narrativas infantis que revelam subjetividades negadas e silenciadas que reforçam a desvalorização de peles negras e indígenas. O que nos interessa é reconhecer a criança como sujeito de direitos e de voz legítima. Por isso, tirá-la da invisibilidade é urgente, para que seja a nossa aliada na luta por uma sociedade antirracista.

E como entendemos que a matéria-prima do processo educativo é de caráter relacional, essa luta só ganha potência quando pensada a partir das relações de alteridade, onde o Outro é Legítimo Outro (MATURANA, 2007).

Neste texto, o nosso Outro se revelou com um grito invisível: 'Tia, se a gente pintar de preto, a cor que eu sou, todo mundo vai achar feio.' Um grito que prendeu sua interlocutora intimamente e a provocou a reafirmar seu compromisso com a educação como prática da liberdade (FREIRE, 1999).

Além disso, foi também um grito que ecoou, para além daquele espaço e tempo ${ }^{70}$, levando muitos a refletirem sobre invisibilidade, representatividade negra e histórias que importam.

E hoje, estamos aqui para contar as experiências instituintes a partir de uma perspectiva histórica baseada na lei federal 10.639/03. Experiências essas, com muitas "artes de fazer" ${ }^{\prime 11}$ dos praticantes do cotidiano (CERTEAU, 1996), cujas narrativas invisíveis muito nos interessam.

Importante ressaltar que a categoria Instituinte, que adjetiva a palavra experiência e que é uma das marcas da RevistAleph, pode ser entendida como o movimento dos sujeitos que pensam e fazem a educação para além das amarras burocráticas e engessadoras que reduzem as ricas experiências que são desenvolvidas, fazendo e refazendo a escola (MOREIRA et.al., 2018, p. 2).

\footnotetext{
${ }^{70} \mathrm{~A}$ emblemática narrativa infantil motivou a professora Kirce Bermute a construir o projeto pedagógico 'Construindo Identidades sob uma perspectiva histórica baseada na lei 10.639'. O projeto foi premiado no 10 Prêmio Paulo Freire da Assembleia Legislativa do Estado do Rio de Janeiro - Alerj na modalidade Experiência Pedagógica no Ensino Fundamental.

${ }^{71}$ Expressão que intitula a consagrada obra de Michel de Certeau, $A$ invenção do cotidiano l: as artes do fazer (1994).
} 


\title{
RevistAleph
}

Cabe dizer que, o lugar das astúcias, das "artes de fazer" e das táticas, é também de onde o professor fala. As narrativas aqui compartilhadas não são meros acasos, porque afinal de contas, ouvir o professor e ouvir o estudante é o que falta às políticas educacionais.

E nesse movimento de compartilhar experiências instituintes no campo do ensino da história da África e Cultura Afro-brasileira e Africana, enfatizamos ao longo do texto, algumas categorias conceituais do historiador Michel de Certeau que contribuem para pensarmos na invenção do cotidiano escolar, pelas mãos dos atores sociais.

As expressões são basicamente: táticas de praticantes, táticas de resistência, ações do tipo tático, inventividade, brechas, e as artes de fazer. Todas elas nos apontam para a direção da desconstrução de práticas discursivas, a partir da não conformidade com o instituído. Mas uma desconstrução baseada na inventividade e criatividade.

Esperamos que os caminhos percorridos pelos praticantes do cotidiano do Ensino Fundamental (4으으 ano) da escola municipal Tiradentes, localizada em Magé/Baixada Fluminense do RJ, inspirem ações do tipo tático a muitos docentes Brasil afora, e quiçá extrapole fronteiras.

\section{De um grande quilombo, nasce um pensar-fazer instituinte}

\author{
É uma história verdadeira \\ Não duvide, tenha fé \\ Contando a trajetória \\ De uma importante mulher \\ Chamada Maria Conga \\ Heroína de Magé \\ (Gilmar Souza - Poeta Cordelista)
}

Magé $^{72}$ é um município da Baixada Fluminense, situado na Região Metropolitana do Rio de Janeiro, localizado ao fundo da Baía de Guanabara. Sua criação nos remete a memórias - em sua maioria, únicas - que os livros didáticos de história narram. É comum vermos a história de Magé sendo iniciada com a figura do português Simão da Mota (Nome da principal

\footnotetext{
72 Segundo dados do IBGE (2019), a população está estimada em 245.071 pessoas.
} 


\section{RevistAleph}

avenida da cidade, inclusive), que no século $\mathrm{XVI}^{73}$ recebeu a doação de uma sesmaria localizada no morro da Piedade, região com forte presença de populações tradicionais (comunidades quilombolas e caiçaras).

As terras mageenses, originariamente habitadas por indígenas, têm fortes marcas dos povos minoritários, ou seja: povos indígenas e quilombolas, sobretudo. A respeito da categoria minoria, é importante ressaltar que:

[...] a categoria minoria pode causar confusão quando referida a grupos de mulheres, negros, indígenas, crianças, população pobre, já que estes representam a maioria. Importante esclarecer que, no discurso hegemônico, minoria dá a ideia de grupo inferior. No entanto, esse conceito na Contemporaneidade vem romper com as questões quantitativas, dando vez às demandas das singularidades dos grupos culturais (PEREIRA, 2016, p.9).

Assim, falar de educação para as relações étnico-raciais nas salas de aulas mageenses, partindo de narrativas locais e das vozes dos sujeitos ordinários do cotidiano (CERTEAU, 1996), representa uma luta pelo fortalecimento das subjetividades dos estudantes, herdeiros de histórias de resistência.

Em Magé, lugar de heróis, tradições e três territórios quilombolas ${ }^{74}$, essa luta se faz urgente. Sim, vivemos e trabalhamos em um grande quilombo e nossa responsabilidade, enquanto profissionais da educação, é assegurar que nossos estudantes se apropriem de suas histórias de maneira afetiva e real. Segundo as Diretrizes Curriculares Nacionais para a Educação das Relações Étnico-Raciais e para o Ensino de História e Cultura Afro-Brasileira e Africana (BRASIL, 2004), a instituição de ensino, bem como as instâncias superiores devem garantir que:

A escola enquanto instituição social responsável por assegurar o direito da educação a todo e qualquer cidadão, deverá se posicionar politicamente, como já vimos, contra toda e qualquer forma de discriminação. A luta pela superação do racismo e da discriminação racial, é pois, tarefa de todo educador, independentemente de seu pertencimento étnico-racial, crença religiosa ou posição política (p. 16).

\footnotetext{
${ }^{73}$ Segundo Sampaio (1994), a povoação de Nossa Senhora da Piedade foi transformada em freguesia em 1696, e elevada à categoria de Vila em 1789.

74 O Quilombo de Maria Conga foi o primeiro território a ser certificado e reconhecido pela Fundação Palmares no ano de 2017. Os Territórios Quilombolas do Feital (Bairro de Piedade/ 1을 Distro) e Kilombá (Bongaba/6으 Distrito) tiveram suas certificações no ano de 2018.
} 


\section{RevistAleph}

No âmbito das políticas públicas, no município de Magé, muito recentemente, alguns passos foram dados com a construção de um dispositivo legal ${ }^{75}$ que inclui a História e Cultura Afro-brasileiras e Indígenas nos currículos da Rede Municipal de Ensino. Não obstante, para a superação de culturas e práticas escolares marcadas por lógicas coloniais, reducionistas e segregadoras da diversidade, ainda há ainda muito o que se conquistar.

E concordamos que as experiências instituintes a partir de uma perspectiva histórica baseada na lei federal 10.639/03, favorecem a construção de uma educação de respeito e diálogo com a cultura africana e afro-brasileira. Afinal, o que deve nos orientar é a garantia dos direitos humanos, que como outrora afirmou Boaventura de Sousa Santos (2013), deve partir de uma concepção multicultural, dialógica e solidária.

\section{Caminhos metodológicos: entre histórias e invenções}

A infância faz parte da sociedade CORSARO ( 1997, p.5)

A Sociologia da Infância (CORSARO, 2005), perspectiva que postula a criança como sujeito histórico, de direitos e com voz competente, se recusa a pensar em uma concepção homogeneizante e passiva da criança. Mas nem sempre foi assim, ou seja, a criança ao longo da história, nem sempre foi reconhecida como ator nas relações sociais. Basta lembrar da expressão iluminista "o homem nasce como se fosse uma tábula rasa", do filósofo John Locke (séc. XVII). Em outras palavras, a criança é um papel em branco, onde o adulto escreve sua cultura.

Até o final do século XX, a imagem da criança passou por várias reestruturações, sendo ela: um miniadulto, sem fala, enfrentou altas taxas de mortalidade, foi reconhecida com alma pela igreja, foi infantilizada e também subestimada em suas invenções. As imagens narradas fazem parte do trabalho do historiador francês, Philippe Ariès.

\footnotetext{
75 Importante destacar a criação de um núcleo de formação para o ensino das relações étnico-raciais no Município. A COPIED (Coordenação de Promoção à Igualdade Étnico-raciais e Diversidade), no qual uma das autoras deste artigo integra, faz parte de um conjunto de políticas públicas municipais que vêm sendo implementadas pela Secretaria Municipal de Educação por meio do Departamento Pedagógico I. A Deliberação CME 006, 15 de março de 2019, por exemplo, é um dispositivo legal que é parte de esforços coletivos de profissionais da educação para a construção de uma educação antirracista na cidade de Magé.
} 


\section{RevistAleph}

Ariès $^{76}$ (1973) é considerado o pioneiro quando se pensa a história da infância. Segundo Seabra e Sousa (2013), Ariès faz parte de um movimento chamado Nova História, onde a infância começa a ser traduzida como uma construção social. Esse movimento também produz novos olhares sobre os métodos e as linguagens da historiografia, favorecendo apropriações múltiplas para a escrita das histórias, como pinturas, fotos, diários e outros artefatos.

Mas, por que discorrer sobre um pensador francês que narrou uma infância única, de uma específica realidade europeia, você deve estar se perguntando. Porque, como já sinalizado anteriormente, Philippe Ariès, é quem anuncia o sentimento de infância na transição da Idade Média para a Modernidade. Ou seja, a infância passa a ser entendida como construção social, desde os escritos de Ariès.

Não obstante, já no final do século XX, quase três décadas após o postulado de Ariès, uma urgência que se colocava: "Crianças estão merecendo estudos como crianças", disse Corsaro (1997, p.95). Era o surgimento do que chamamos de Sociologia da Infância, onde os estudos da infância são legitimados como campo científico (SARMENTO, 2005). Diversos e diferentes são os pesquisadores, partindo da Europa, que nos anos 90 se dedicaram a pensar as crianças como sujeitos ativos e criativos, capazes de criar culturas: as suas próprias e as do mundo adulto.

E se, como William Corsaro, concordamos que a infância é parte da sociedade, somos convidados a agir taticamente por caminhos metodológicos que amplifiquem suas vozes, para que junto delas, criemos "artes de fazer" instituindo um novo mundo, a partir de sua própria realidade.

Somos provocados também a refletir sobre a legitimidade e complexidade da criança, não mais sobre suas vozes invisíveis. Mas com as suas vozes que bradam e expressam saberes, dialogando com as diferentes áreas do conhecimento: história, sociologia, psicologia, filosofia, antropologia, tecnológica e tantas outras. Segundo Pereira $(2016$, p.28), pensar a

\footnotetext{
${ }^{76}$ Autor da produção historiográfica: A Consagrado pela obra: História Social da Criança e da Família na década de 60. Ariès (1978). Ariès, descreveu a infância europeia a partir do século XII, explicitando o sentimento sobre a infância, seu comportamento nas relações sociais e na família. Apesar da grande contribuição no campo da Infância, sua obra sofreu críticas por retratar uma única realidade, a europeia. Desconsiderando as outras infâncias, sobretudo as crianças pobres e de classes populares.
} 


\section{RevistAleph}

criança a partir do entrelaçamento dessas ciências é conferir-lhe status de um ser social complexo e em devir.

Nesse caminho, onde a criança é um entrelaçamento de ciências, saberes e histórias, a pesquisa etnográfica foi ganhando forma. Segundo Kramer (2002), essa alternativa garante procedimentos metodológicos e estratégias favoráveis às interações adulto e criança (p. 44).

Manuel Sarmento (2011), pesquisador português das Infâncias, disserta sobre à etnografia na educação. Para o autor,

[...] etnografia visa apreender a vida, tal qual ela é quotidianamente conduzida, simbolizada e interpretada pelos actores sociais nos seus contextos de aç̧ão. Ora, a vida é, por definição, plural nas suas manifestações, imprevisível no seu desenvolvimento, expressa não apenas nas palavras mas também nas linguagens dos gestos e das formas, ambígua nos seus significados e múltipla nas direcções e sentidos por que se desdobra e percorre (p. 17).

Outro caminho metodológico adotado, e que converge com a etnografia, foram os Projetos de Trabalho (HERNANDEZ, 1998). Essa metodologia permite a construção de alternativas coletivas, reflexivas e interativas com diferentes saberes, que por vezes estão silenciados no cotidiano.

A professora desta narrativa, entendeu que a organização do currículo por Projetos de Trabalho, tratava-se de uma maneira de fortalecer os protagonismos dos atores daquele cotidiano, evidenciando seus desejos, suas potencialidades, suas dúvidas, percepções sobre si e sobre o mundo. Além de mobilizar a aprendizagem de maneira prazerosa.

Por exemplo, aprender sobre números romanos, pode ser envolvente se dialogados com outros componentes curriculares que não sejam a matemática e sua linguagem técnica. Porque não mesclar a Arte, a Filosofia e a História da África para provocar a curiosidade dos alunos e positivar as relações étnico-raciais?

Pesquisar sobre a biografia de mulheres feministas e perceber a influência das mulheres negras que exerceram protagonismos na sociedade brasileira, pode ser inspirador. Principalmente para as meninas negras. Desenhar em tela sua imagem, com uma diversidade de cores e traços, é uma forma de demonstrar que suas histórias importam.

Um desafio constante para a realização dos Projetos de Trabalho é a superação da fragmentação do conhecimento pela interdisciplinaridade. A razão de ser desse desafio está na forte cultura conservadora das instituições de ensino, onde algumas, ainda insistem em 


\title{
RevistAleph
}

organizar os alunos na sala de aula sentados em fileiras, onde o professor é tido como detentor do saber e as disciplinas são ensinadas de maneira isolada.

Encontramos em Michel de Certeau (1996), respostas para superar este desafio, visto que sua proposta é inverter perspectivas instituídas com criatividade e táticas, nesse campo estratégico que é a escola. Vale ressaltar aqui, que as ferramentas para enfrentar esse desafio foram variadas: registros em caderno de campo, produção biográficas, exibição de audiovisual, utilização de recursos tecnológicos e digitais.

Muitos foram os saberes, os modos e os artefatos envolvidos para a reinvenção do cotidiano. E reconhecemos que essa reinvenção, só foi possível no tempo da experiência e do acontecimento (tempo também da incerteza), como já afirmava Deleuze (KOHAN, 2002).

Jorge Larrosa (2011) reforça essa ideia, complementando que a experiência está cada vez mais rara. E considerando que vivemos em um mundo globalizado e com uma crescente nas lógicas técnico-científicas, viver experiências plenas, de construção coletiva de saberes artesanais e de afirmação da diversidade humana, é afirmar as vozes e expressões da Infância enquanto potencializadoras de nossa ação transformadora no mundo. Expressões essas, interpretadas como as artes de fazer dos praticantes do cotidiano que se movem no campo das estratégicas e com imaginação, ludicidade, simbolismo, criatividade e táticas, reavivam a prece: Oh, meu corpo, faça sempre de mim um homem que questiona!

\section{Reinventando o cotidiano com as artes de fazer mediado por histórias que importam}

\begin{abstract}
se a produção e a transmissão do saber, na escola, não forem mediados pela particularidade cultural da população negra, as práticas pedagógicas continuarão punindo as crianças negras que o sistema de ensino não conseguiu ainda excluir, aplicando-lhes o seguinte castigo: reclusão, ritualizada em procedimentos escolares de efeito impeditivo, cujo resultado imediato é o silenciamento da criança negra, a curto prazo, e o do cidadão, para o resto da vida
\end{abstract}

GONÇALVES (1987, p. 29).

Ao afirmar que a criança é produtora de culturas na relação entre pares e também entre adultos, a Sociologia da Infância, rompe com teorias funcionalistas que outrora a identificaram como reprodutora e condicionada às normas da sociedade. William Corsaro 


\title{
RevistAleph
}

(2005), inaugura a categoria conceitual chamada Reprodução Interpretativa, onde defende a capacidade de interpretação e transformação que têm as crianças.

Em outras palavras, a expressão Interpretativa é entendida pela forma inventiva e criativa da criança de participar de suas culturas. Já a expressão reprodução, refere-se à sua capacidade para a reprodução da sociedade ou para a mudança social.

Com esse entendimento, Pereira (2016) nos provoca a realizar as seguintes perguntas: qual é a cultura escolar na qual nossas crianças têm sido formadas? Esse meio tem favorecido o reconhecimento de suas subjetividades a partir de suas diferenças? Esse meio tem provocado a inclusão da diversidade étnico-cultural nos espaços educativos e fora deles? Com as narrativas que seguem, vamos respondendo essas e outras perguntas, que podem também ser a de muitos outros docentes.

\begin{abstract}
...fiz uma breve entrevista com os alunos, a fim de entender qual era a origem da negação de sua etnia. Percebi que as crianças ou suas famílias já tinham sofrido casos de racismo, inclusive dentro da escola. Quando comecei a ouvir os relatos dos alunos, surgiu a necessidade de estudarmos sobre a origem do bairro e da comunidade. Foi quando descobrimos que alguns alunos têm origem em uma comunidade Quilombola, próximo à escola e outros alunos são descendentes de pessoas que foram escravizadas. Estas, logo após a abolição da escravatura, se instalaram no bairro, para o trabalho na lavoura e o campesinato (Registro do caderno de campo. BERMUTE, 2019). ${ }^{77}$
\end{abstract}

O exercício de uma escuta atenta e de observação constantes é fundamental para construir experiências afetivas e com sentido para os discentes e também para nós docentes. Outrora, ouvi dizer que de um óleo quente se faz pipocas. E é justamente a partir da sistematização desses sentidos que foi possível criar estratégias para ampliar as culturas locais e também ressignificá-las.

O óleo quente talvez tenha sido, objetivamente, o fato das crianças não se reconhecerem como negras, terem vergonha de sua cor e sequer saberem que eram oriundas de um território de remanescentes quilombolas ${ }^{78}$. Era visível que tudo isso gerava uma crise de identidade. E foi possível perceber à medida que as crianças se recusavam a pintar seu

\footnotetext{
${ }^{77}$ A partir desses dados, procurei a direção e a equipe pedagógica de unidade escolar para falar sobre a ideia do projeto. Tive o aval para iniciar as ações referentes ao projeto "Construindo Identidades".

${ }^{78}$ A escola M. Tiradentes fica localizada em um bairro vizinho ao bairro de Bongaba (6o Distrito de Magé), onde existe um território de remanescente quilombola e onde alguns alunos da turma vivem.
} 


\section{RevistAleph}

autorretrato com cor diferente. Essas percepções provocaram o aprofundamento da discussão.

Com isso, houve a necessidade de realizar um encontro com os pais e responsáveis para apresentar a ideia do projeto que estava nascendo. Isso implicava em evidenciar para eles diferentes questões, como: sobre as narrativas de seus filhos e filhas, as ideias das crianças, a origem de algumas famílias do bairro e também as atividades que seriam desenvolvidas na escola e na/com a comunidade.

Tudo isso, desdobrou em reflexões a respeito da importância de fortalecer as identidades dos estudantes e assim minimizar os preconceitos latentes na turma e na unidade escolar. Essa interlocução com a comunidade de pais e responsáveis foi positiva e dialógica, pois os mesmos abraçaram a ideia, solicitando que o projeto se estendesse a toda escola.

Sem dúvida, o provérbio africano que diz que é preciso uma aldeia para educar uma criança nunca fez tanto sentido. Nunca fez tanto sentido a cultura de pares e intergeracional (SARMENTO, 2005), na produção de relações étnico-raciais mais saudáveis e acolhedoras.

Assim, com a mediação de diferentes atores no processo educativo, as artes de fazer docentes e discentes vão ganhando potência. Importante salientar que o projeto se constitui de 10 etapas, que foram sendo construídas de acordo com os indícios e as solicitações das crianças. A primeira atividade foi a construção do documento de identidade, onde foi consolidado a escrita do nome (escrita correta do substantivo próprio, filiação).

Logo em seguida foi construída a árvore genealógica, para trabalhar o sobrenome. Outra criação diferente de tudo que os estudantes já tinham feito foi um acróstico com o primeiro nome. Nele, foi pedido para colocar palavras e símbolos que tivessem a ver com a personalidade de cada um.

Ações envolvendo a literatura infantil também fizeram parte das experiências. Tudo começou com o Piquenique Literário Africanidades - nome dado pelos próprios estudantes, desejo dos estudantes que gostariam de, ao menos uma vez, usar o jardim da escola para ler. Ao ar livre, no jardim da escola, vários títulos infantis sobre a temática racial e equidade foram lidos. Esta experiência aconteceu no mês de abril, em memória ao Dia do livro infantil. 


\section{RevistAleph}

Figura 1. Piquenique literário Africanidades

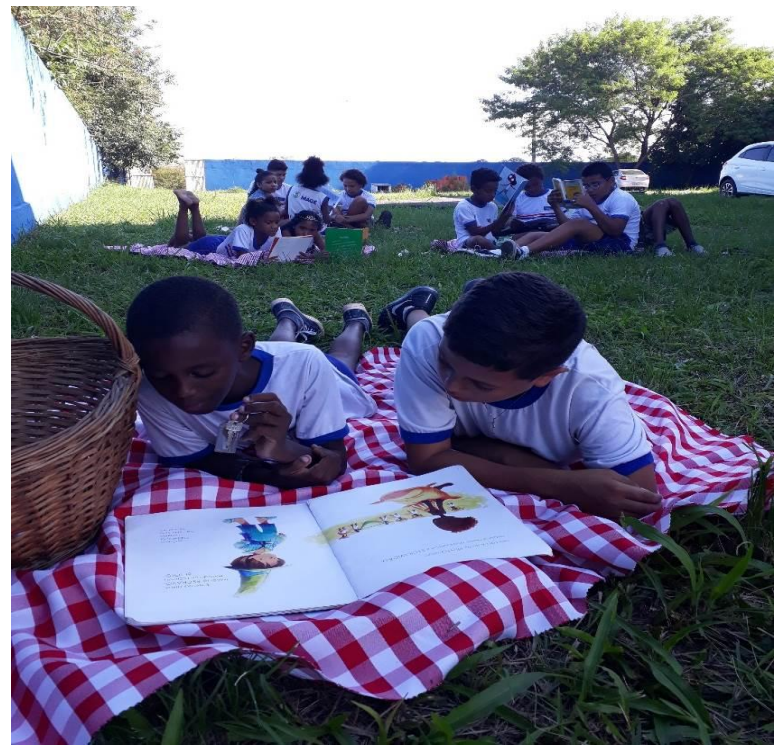

Fonte: Arquivo pessoal das autoras

A experiência inicial envolvendo a literatura foi crescendo conforme os indícios que os estudantes iam apresentando. Assim, surge a "Hora da leitura"79, onde um dos livros adotados foi: Kiese, história de um africano no Brasil ${ }^{80}$, que fala da trajetória de um menino que é capturado, ainda criança, em sua aldeia, na África. E que chegando ao Brasil, passa a ser escravizado e tem a sua juventude e vida adulta vivida nas amarras da escravidão.

A partir da leitura desse livro, foi estabelecido conversas sobre História do BrasilColônia e Matemática, visto que a obra trata da virada do século. Dessa maneira, a linguagem matemática foi adaptada às atividades por meio dos números romanos.

O trabalho com o conteúdo de matemática teve êxito, afinal de contas, muito distante do que muitos pensam, não é o conteúdo ou o tema que chamará a atenção dos estudantes, mas a forma como ele é tratado. Segundo a historiadora Márcia Guerra (2019), quase todo tema pode ser instigador. O que vai mobilizar a turma é o processo de aprender.

E a organização do currículo por Projetos de Trabalho é um caminho para tal, porque, como falado anteriormente, é uma metodologia que vê no estudante um protagonista que

\footnotetext{
79 Paralelo à "Hora da leitura", existia o livro itinerante "O amigo do rei". Cada criança levava para casa, até que toda a turma tivesse lido. Outras obras foram adotadas. Cabe ressaltar que, foram feitos fichamentos de todos os títulos lidos, trabalhando gêneros textuais e sua estrutura, além de trabalhar produção textual, já que os alunos eram estimulados a escrever sua opinião sobre o título lido.

${ }^{80}$ Kiese. História de Um Africano no Brasil (2015). Autor: Ricardo Dreguer. Editora: Moderna.
} 


\section{RevistAleph}

pensa, interage, se interessa, tem dúvidas, que busca, que pesquisa, que se organiza, que constrói e difunde o conhecimento.

Assim, foi possível desconstruir com as crianças, por meio da literatura, a imagem da monarquia brasileira e de uma sociedade que baseou a sua economia e o seu crescimento em um sistema escravista. Essa descoberta foi impactante para todos, pois acreditavam em uma monarquia glamourosa, baseada nos contos de fadas, de princesas, príncipes, reis e rainhas bondosos.

E se por razões históricas e ideológicas, as diferentes linguagens, sobretudo as orais, ficaram secundarizadas na escola. E nosso papel, enquanto praticantes do cotidiano, é fazer emergir essas linguagens e colocá-las a nosso favor.

Nossa sociedade valoriza muito mais a linguagem escrita por ter na história um apelo forte a cultura grafocêntrica. Não obstante, se sabemos que somos herdeiros de povos africanos e afro-brasileiros, vale reconhecer que estes prezam como valor outros modos de expressão, como a oralidade, a musicalidade, a corporeidade, a ludicidade e tantos outros.

Figura 2: Animais da Savana Africana

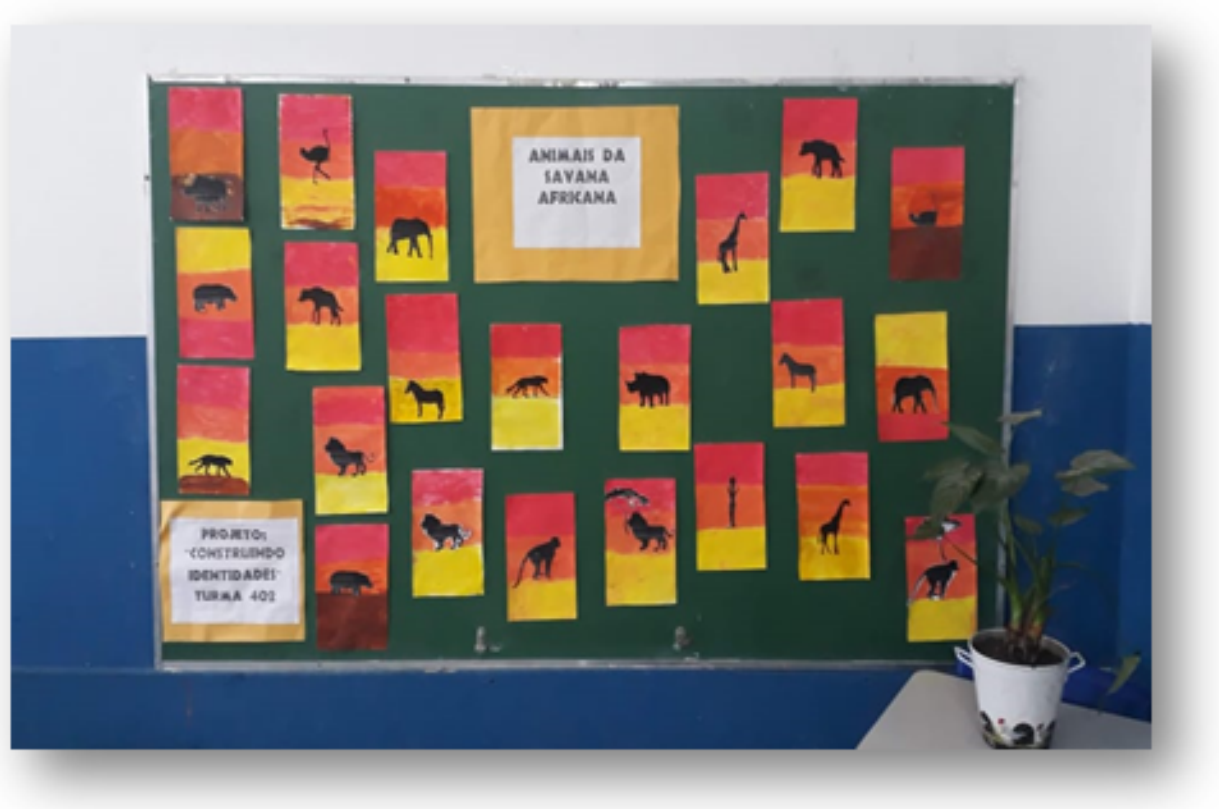

Fonte: Arquivo pessoal das autoras 


\section{RevistAleph}

Assim, os princípios afro-brasileiros (TRINDADE, 2013) da musicalidade, corporeidade e energia vital se fizeram presentes por meio do videoclipe da música África da Palavra Cantada ${ }^{81}$. Entre brincadeiras, danças e cantorias, as crianças sinalizavam na música as palavras, as quais, desconheciam o significado.

As descobertas foram mediadas pela internet e por dicionários. Também foi possível trabalhar encontros vocálicos e interpretação de texto. Além de usar a criatividade na hora de colorir alguns símbolos africanos, como animais da Savana ${ }^{82}$, máscaras africanas, formato do continente Africano. Teve até confecção de colares africanos com papelão e apresentação coreografada na roda africana.

Figura 3: As Artes de fazer dos autores do cotidiano

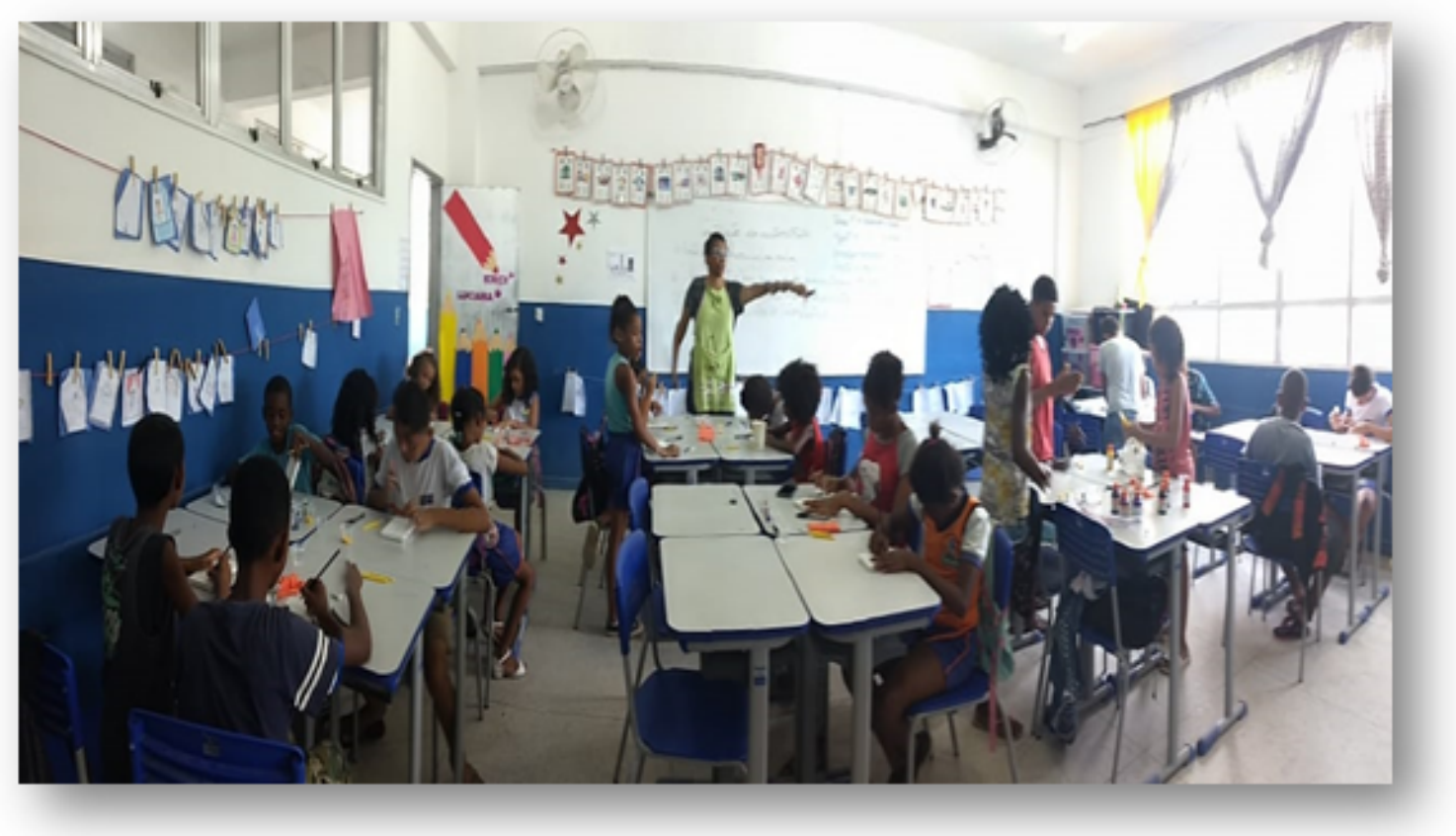

Fonte: Arquivo pessoal das autoras

Outra experiência instituinte envolvendo a música, foi a exibição do videoclipe $A$ carne de Elza Soares ${ }^{83}$, onde os estudantes produziram um texto coletivo sobre racismo e

\footnotetext{
${ }^{81} \mathrm{O}$ videoclipe pode ser encontrado no Youtube pelo link:https://www.youtube.com/watch?v=yGv47mv7874

82 Nesse processo, houve discussão sobre animais em extinção e diferentes tipos de biomas. Cada criança escolheu um animal fazendo seu fichamento, nome, habitat e alimentação.

${ }^{83} \mathrm{O}$ videoclipe pode ser encontrado no Youtube pelo link: https://www.youtube.com/watch?v=yktrUMoc1Xw
} (c) (i) (2) 


\section{RevistAleph}

preconceito. O título do texto foi "O racismo no Brasil". Com isso, foram desdobradas atividades envolvendo estrutura de um texto e gêneros textuais.

Em seguida, teve produção acróstico, por sugestão da própria turma, porque gostaram da experiência anterior. A palavra utilizada para o acróstico foi RACISMO. Por meio da música, também foi possível trabalhar a leitura de gráficos, as diferenças entre negros e brancos no que tange ao trabalho infantil, analfabetismo, distorção idade-série, matrículas no ensino superior e vítimas de homicídios. ${ }^{84}$ Cabe ressaltar que as crianças ficaram impactadas com o vídeo e os gráficos, expressando que aquele foi "um dia triste".

Mas reinventar os dias, a partir de nós mesmos, sempre é possível. Afinal, somos herdeiros de homens, mulheres, crianças e idosos que atravessaram o Oceano Atlântico em meio a dores e saudades, mas nem por isso perderam a capacidade de sonhar, cantar, dançar, brincar e refletir.

Figura 4: Telas de Autorretratos em circularidade

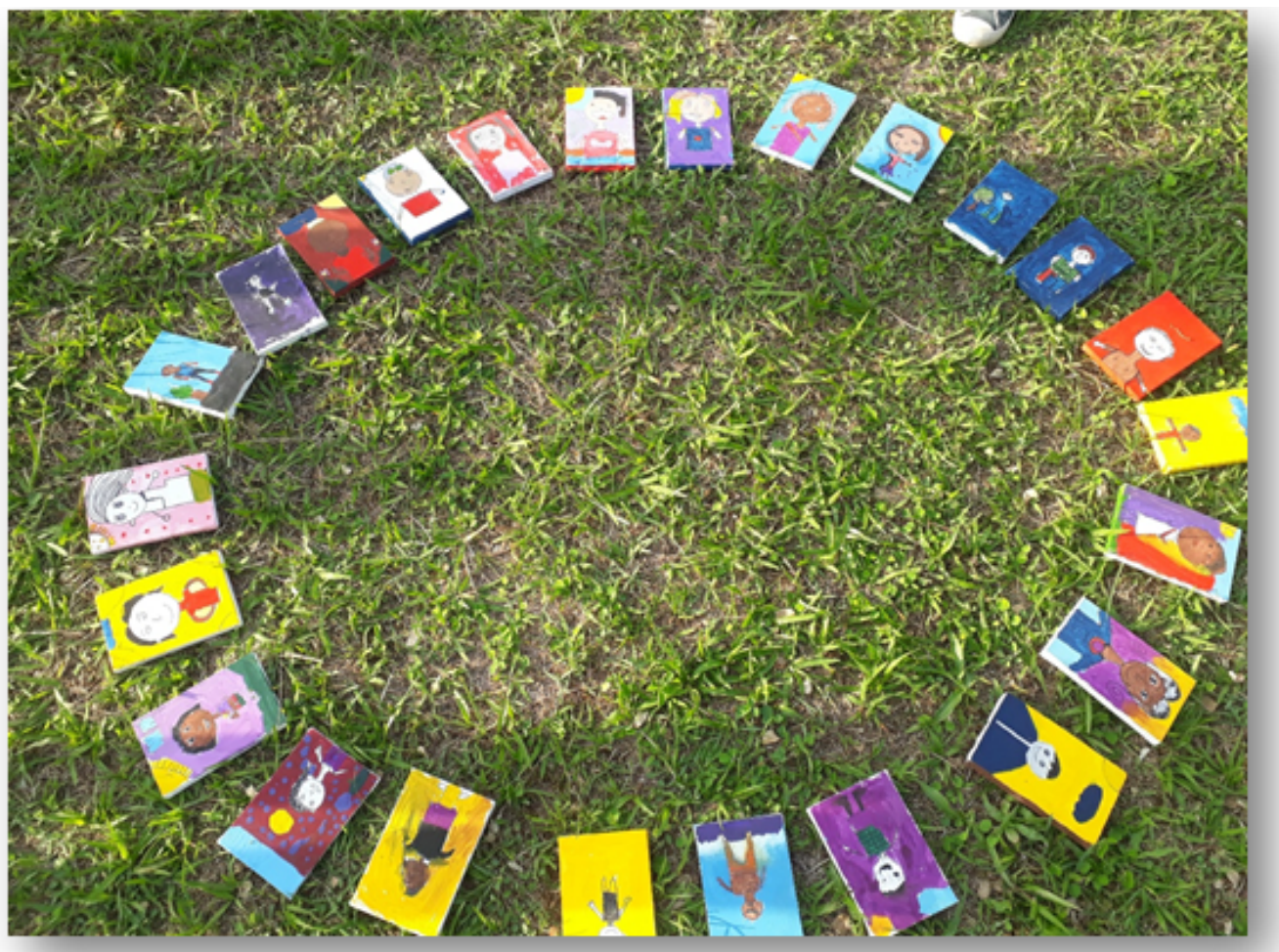

Fonte: Arquivo pessoal das autoras

\footnotetext{
${ }^{84}$ Nesse processo, os estudantes construíram gráficos de mapeamento após coleta de dados sobre a quantidade de negros nas famílias da comunidade escolar que concluíram o ensino Fundamental, médio e superior.
} 
E esse amor guardado em mim Sou bem capaz de uma nuvem tocar

Eu vou seguir muito agradecida

Pelo bom e o ruim dessa vida

E o principal

Sou grata por amar quem eu sou

É que eu sou bonita sim

E estou aqui

Celie (A Cor Púrpura) ${ }^{85}$

Sim, estamos aqui! Meninas, meninos, docentes e comunidade escolar bradando que nossa história importa. Bradamos também que nossa capacidade de sonhar, cantar, dançar, brincar e inventar, resiste! E com táticas continuaremos anunciando o quanto somos bonitos e capazes de reinventar o cotidiano com nossas artes de fazer.

Desse modo, imbuídos de saberes potencializadores de pertencimento étnico-racial, os estudantes construíram seus próprios autorretratos. E se o autorretrato é uma representação que o artista faz de si mesmo, as crianças tiveram a oportunidade de se retratarem enquanto atores inventivos que são ${ }^{86}$.

Por meio das pinturas é possível perceber a desconstrução de identidades dominantes e também de um fetichismo epistêmico (OLIVEIRA; CANDAU, 2010) que despreza outras formas de beleza que não europeias. E essa reflexão não ficou de fora. Com a transposição didática necessária, após a pintura, foi feita uma roda de conversa, bem descontraída, onde as crianças foram provocadas a falar sobre suas criações.

Importante destacar que elas ficaram mais à vontade em misturar as cores e retratar a cor de sua pele como realmente parece ser. Logo, a narrativa inicial "não pinto de preto, porque vão achar feio", não teve espaço nessa experiência diante do prazer e liberdade que vivenciaram. Como diz Larrosa, foram experiências que os atravessaram, e nós completamos: foram experiências que os tornaram livres.

\footnotetext{
85 Trecho do musical A Cor Púrpura da Broadway. A música "I'm Here", na sua versão em português foi interpretada pela artista mageense Letícia Soares, que protagoniza a adorável Celie. A história original foi escrita pela autora, poetisa e feminista negra Alice Walker.

${ }^{86}$ Em uma tela de algodão, usando tinta pva. A partir dessa atividade, foram trabalhadas cores primárias, secundárias e terciárias. Além de texturas, misturas de cores, contorno e sombreamento.
} 


\section{RevistAleph}

Figuras 5 e 6: Pintura em telas
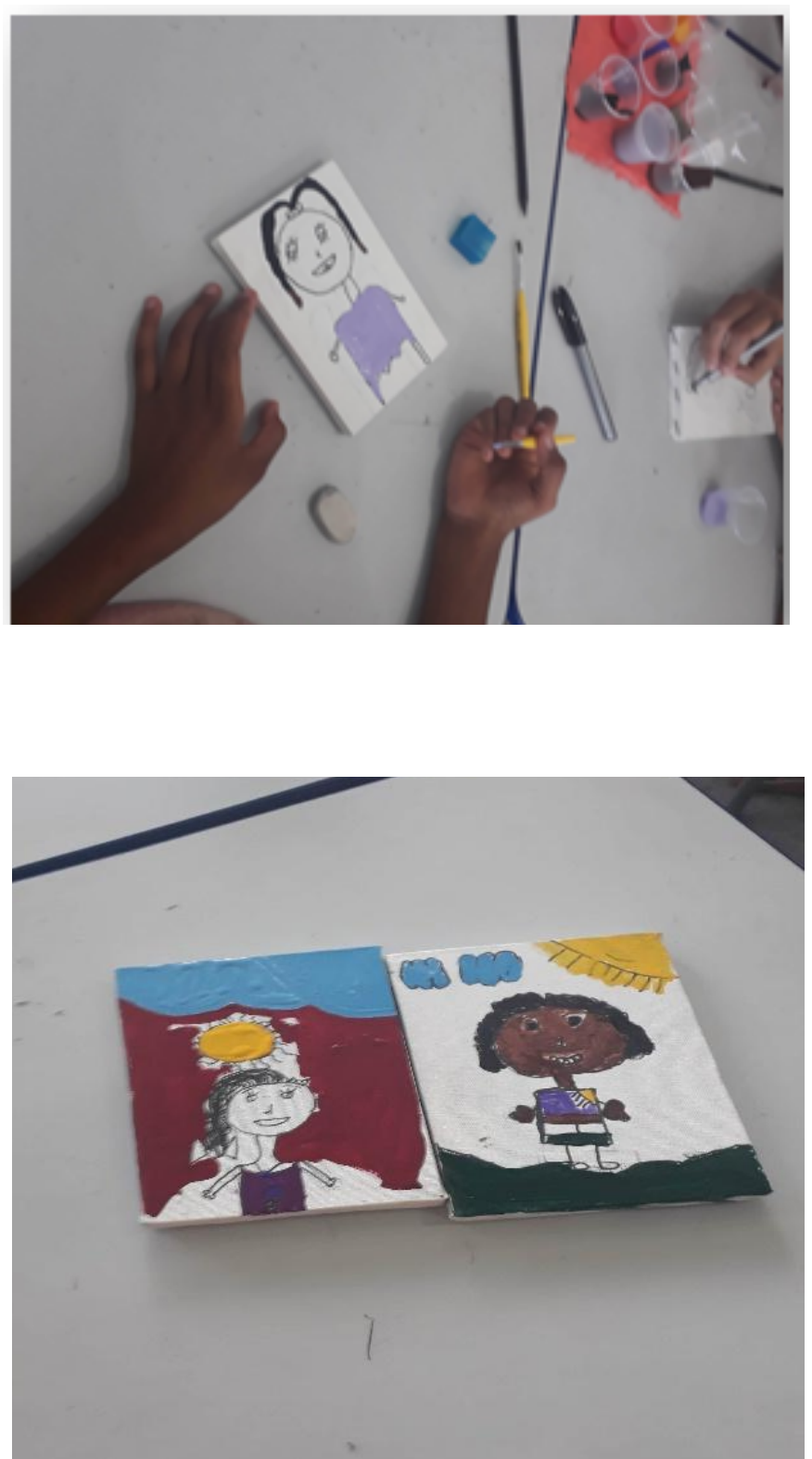

Fonte: Arquivo pessoal das autoras 


\section{RevistAleph}

Figura 7: Pintura de telas da turma

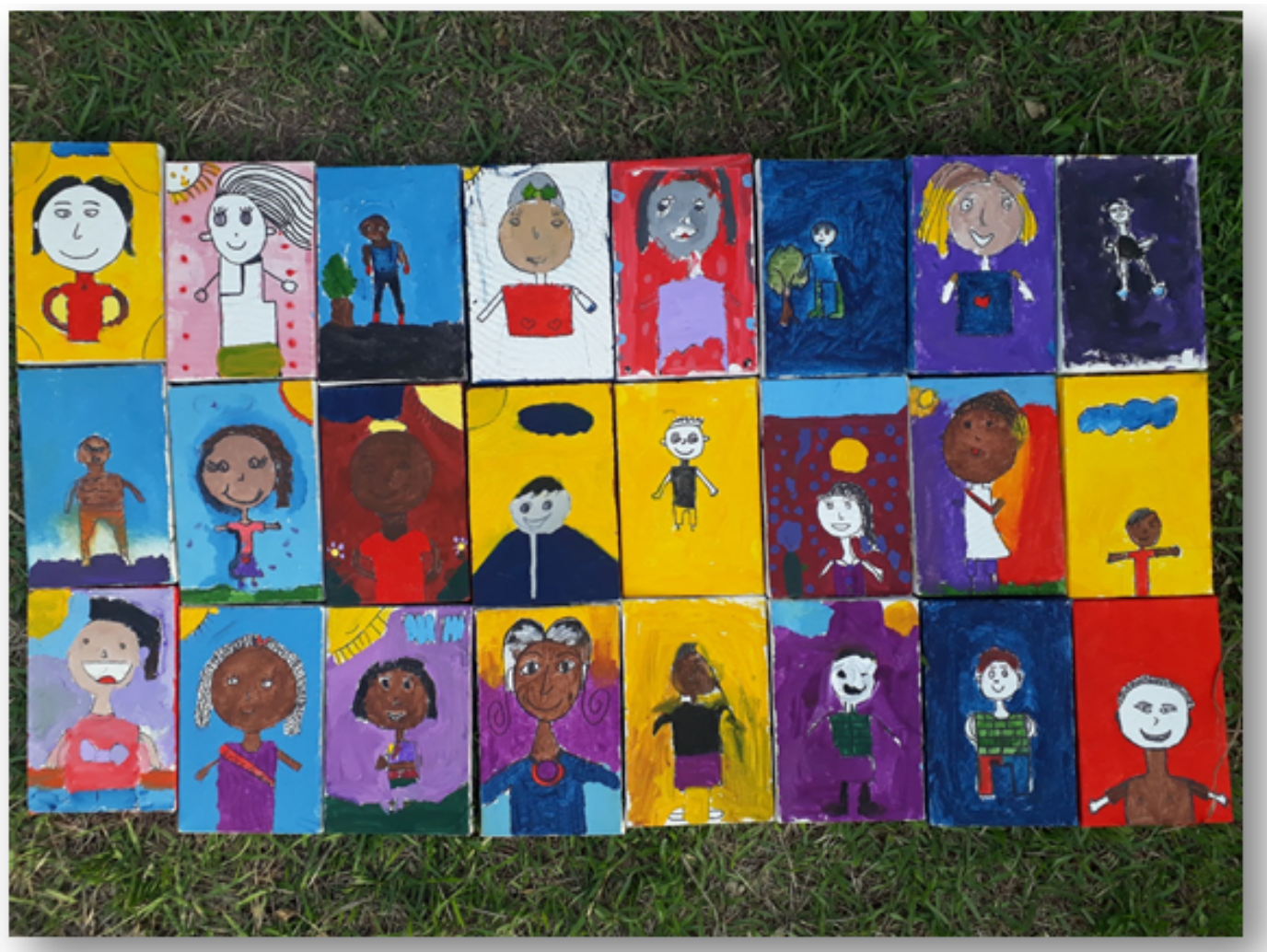

Fonte: Arquivo pessoal das autoras

A atividade de pintura do autorretrato, respondeu a provocação que justificou esse projeto, que era a falta de representatividade negra de uma turma e também o não pertencimento a uma comunidade com tantas histórias bonitas e que por isso, coloridas e dinâmicas. Se essa ação fosse realizada no início, sem percorrer caminhos reflexivos, ativos, interativos e colaborativos, este projeto não se configuraria como uma grande experiência instituinte.

\section{Um encontro precioso com Paulo Freire na ALERJ}

Ensinar exige a convicção de que a mudança é possível.

Paulo Freire (1996)

Paulo Freire, patrono da educação brasileira, sempre soube que a esperança é um ato insurgente, que pequenas resistências constroem liberdades, mesmo que miúdas. No 


\section{RevistAleph}

entanto, para os atores (docente, discentes e comunidade) da escola Municipal Tiradentes, localizada aos Fundos da Baía de Guanabara, essa liberdade era sua maior riqueza.

Pelas mãos da deputada estadual Renata Sousa (PSOL), a professora Kirce Bermute e seus alunos, recebem o 10 Prêmio Paulo Freire da Assembleia Legislativa do Estado do Rio de Janeiro - Alerj na modalidade Experiência Pedagógica no Ensino Fundamental.

Figura 8: 1올 Prêmio Paulo Freire na ALERJ

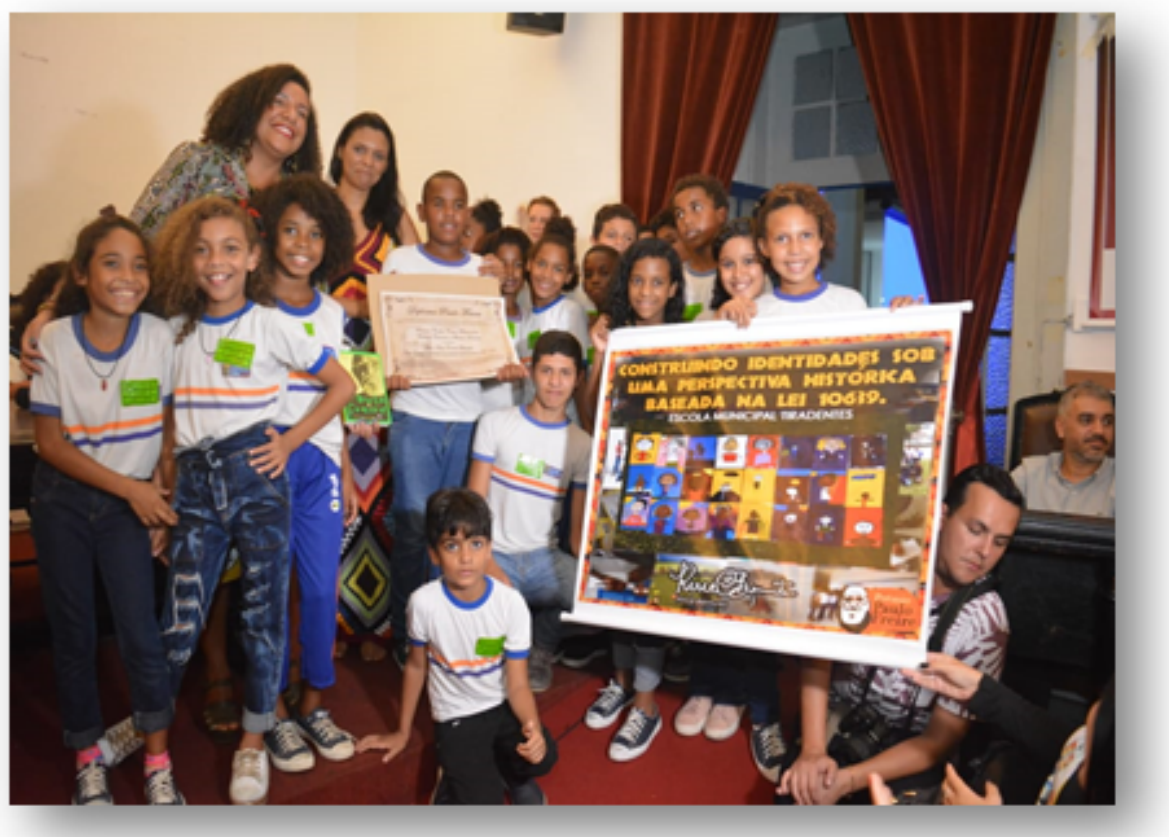

Fonte: Arquivo pessoal das autoras

\section{Caminhando para a conclusão...}

Aprender com o passado, para transformar o presente e mudar o futuro Adinkra Sankofa

Iniciamos este artigo, chamando Frantz Fanon para a conversa. Este autor, com tudo o que representa em sua trajetória acadêmica e militância antirracista, nos inspira. A construção de subjetividades outras no espaço escolar, a partir de uma perspectiva histórica baseada na lei federal 10.639/03, tem muita influência de seu pensamento, já que o mesmo defendia não só uma luta de ideias, mas uma luta prática de reinvenção e libertação do ser humano (PEREIRA, 2019). 
Figura 9: Conhecendo e produzindo Adinkras

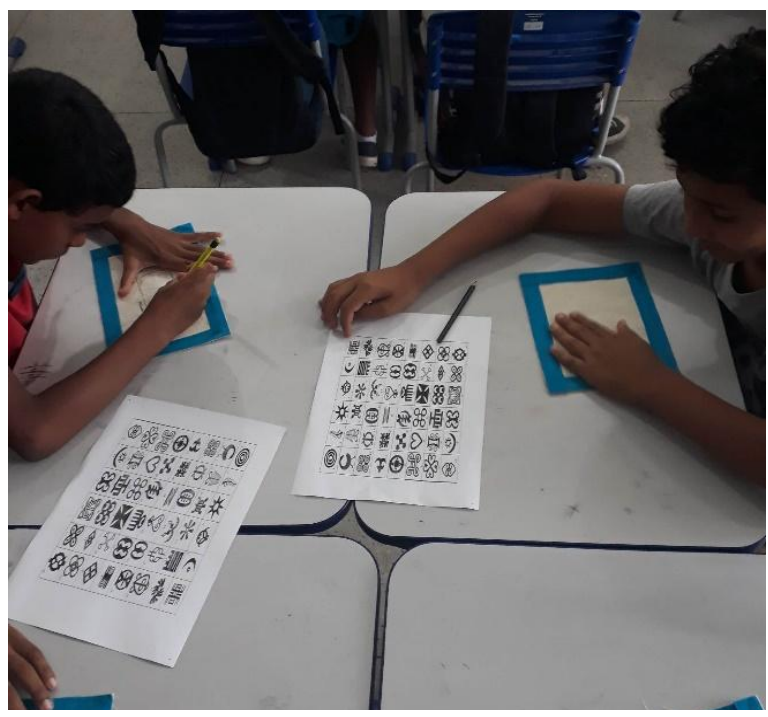

Figura 10: Varal de Adinkras

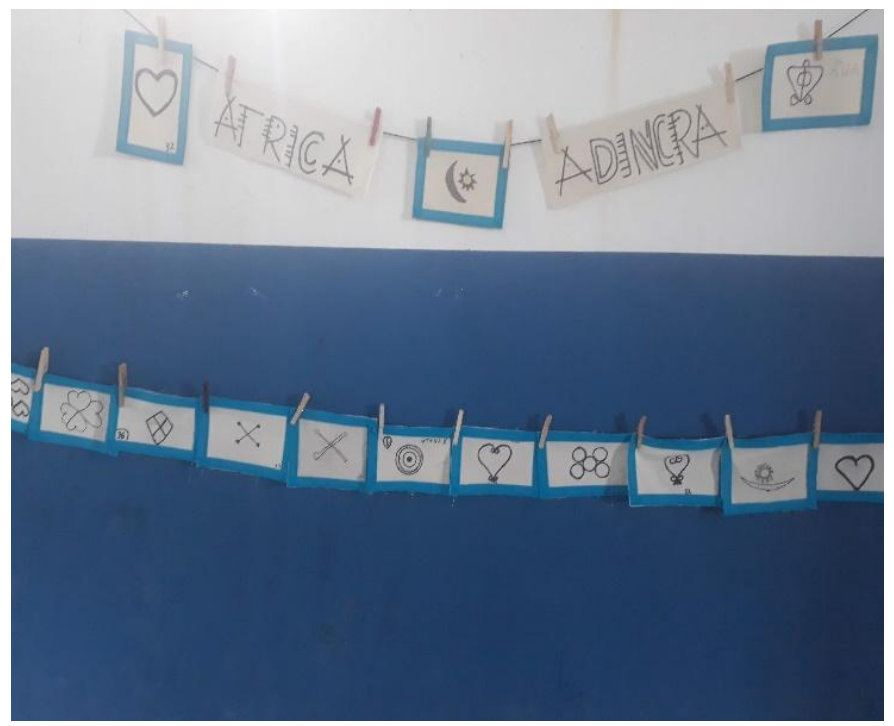

Fonte: Arquivo pessoal das autoras (ambas)

As imagens acima, traduzem essas lutas. Nelas, vemos os símbolos africanos Adinkras, ${ }^{87}$ apropriados e reinventados pelos atores do cotidiano. Estes símbolos representam um sistema de escrita pictográfica e carregam ideias sobre respeito, ancestralidade, sabedoria, crenças e comportamentos. Um Adinkra muito conhecido é o Sankofa (representado por um pássaro olhando para trás). Ele representa o desafio da humanidade de aprender com o passado esquecido e negado, para inaugurar um novo presente e sonhar com um futuro diferente. ${ }^{88}$

E é claro que as crianças entenderam o quanto o projeto Africanidades, iniciado no início do ano letivo, ${ }^{89}$ tinha relação com todos esses símbolos e os saberes que carregam. Assim, cada estudante produziu seu Adinkra, justificou sua escolha e presenteou a família. Essa experiência consolidou a participação da família naquele fim de ano letivo, de modo afetivo e simbólico.

\footnotetext{
${ }^{87}$ Os símbolos Adinkras, faz parte de um sistema de escrita pictográfica, criados pelos povos Akan, presentes em Gana, Costa do Marfim e no Togo, países da África do Oeste.

Fonte: http://www.acaoeducativa.org.br/relacoesraciais/adinkras/

${ }^{88}$ A professora Kirce, autora deste artigo, fez um vídeo falando sobre os Adinkras e os tempos difíceis que estamos passando. Vem ver! Link: https://www.facebook.com/1076138872447298/videos/686627035478774/ 89 O Projeto Africanidades foi o nome dado pelos estudantes ao projeto do Piquenique Literário.foi uma proposta da Secretaria de Educação para o segundo semestre de 2019.
} 


\section{RevistAleph}

Dialogar com a Sociologia da Infância, enquanto campo científico, que concebe a infância como objeto sociológico, foi um caminho que se fez necessário por entendermos que as vozes infantis importam na construção de uma sociedade antirracista.

A continuidade deste trabalho no ano de 2020, se sustentou nos princípios já adotados e também em princípios da etnografia longitudinal (CORSARO, 2005), no sentido de dar continuidade ao processo acompanhamento dos estudantes na transição para o 5 o ano do Ensino Fundamental. Segundo Delgado e Muller (2005, p. 171), a etnografia longitudinal é recomendada por William Corsaro como o método ideal para documentar as associações, envolvendo crianças em suas culturas e focalizando os períodos de transição da vida delas.

E como acreditamos que teorias funcionam como lupa para enxergarmos melhor o cotidiano, compartilhamos a seguir flashes das primeiras semanas do ano de 2020. Era o início do mês de março, onde se comemora o Mês da Mulher e também da Luta Internacional pela Eliminação da Discriminação Racial ${ }^{90}$. Foi solicitado aos estudantes uma pesquisa sobre mulheres sobre feministas brasileiras. "Curiosamente" ${ }^{91}$, doze crianças levam biografias de Maria Firmina dos Reis, outras crianças levaram biografias, das mais variadas, não menos importantes que a de Maria Firmina. São elas: Conceição Evaristo e Daiane dos Santos e Maria da Penha. Abaixo, compartilhamos narrativas infantis (palavras e imagens) que expressam os rituais de passagem (com uma nova compreensão sobre identidade negra) não só das crianças, como das culturas escolares (DELGADO e MULLER, 2005, p. 171).

Eu escolhi a Maria Firmina porque ela foi professora. Porque ela é negra. Por isso escolhi ela.

(Narrativa infantil - autora: Geovanna Alves)

Eu escolhi a Maria Firmina dos Reis porque ela escreveu um romance. Ela foi a primeira romancista brasileira. (Narrativa infantil - autor: Bruno Caillon)

${ }^{90}$ As escolas municipais rememoram o Dia 21 de março (Massacre de Shaperville), como um passado que não pode se repetir. Ao longo do mês de março, acontecem ações nas escolas inspiradas na Campanha estadual " 21 Dias de Ativismo Contra o Racismo".

${ }^{91}$ Vale ressaltar que a solicitação foi uma pesquisa sobre mulheres, brasileiras, ativista dos direitos da mulher. (c) (i) (2) 


\section{RevistAleph}

Figura 11: Varal "Mulheres Africanas"

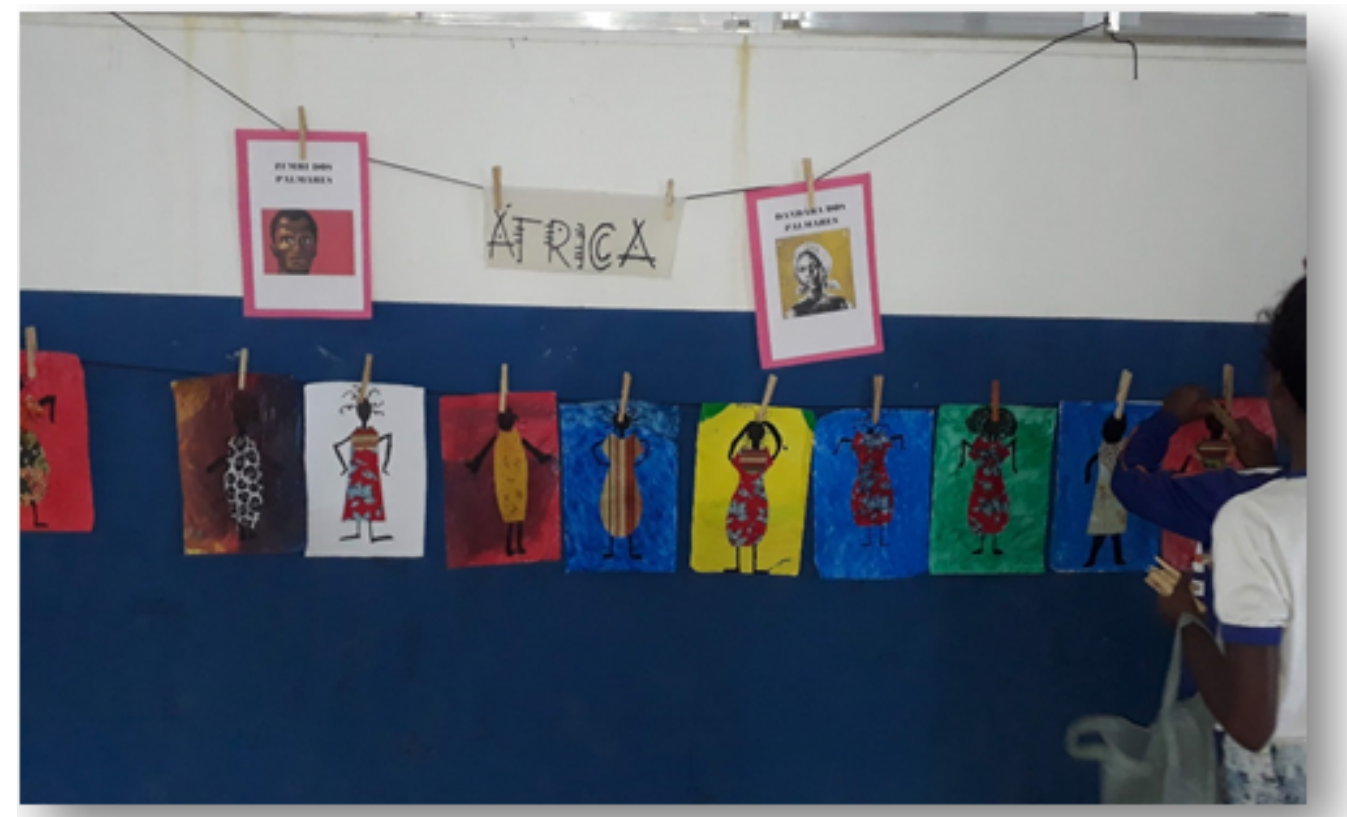

Fonte: Arquivo pessoal das autoras

Figura 12: Avaliação de um dos estudantes sobre o projeto

8 ) Escreva com suas próprias palavias sobre o nosso projeto " Construçăo de Identidade ":

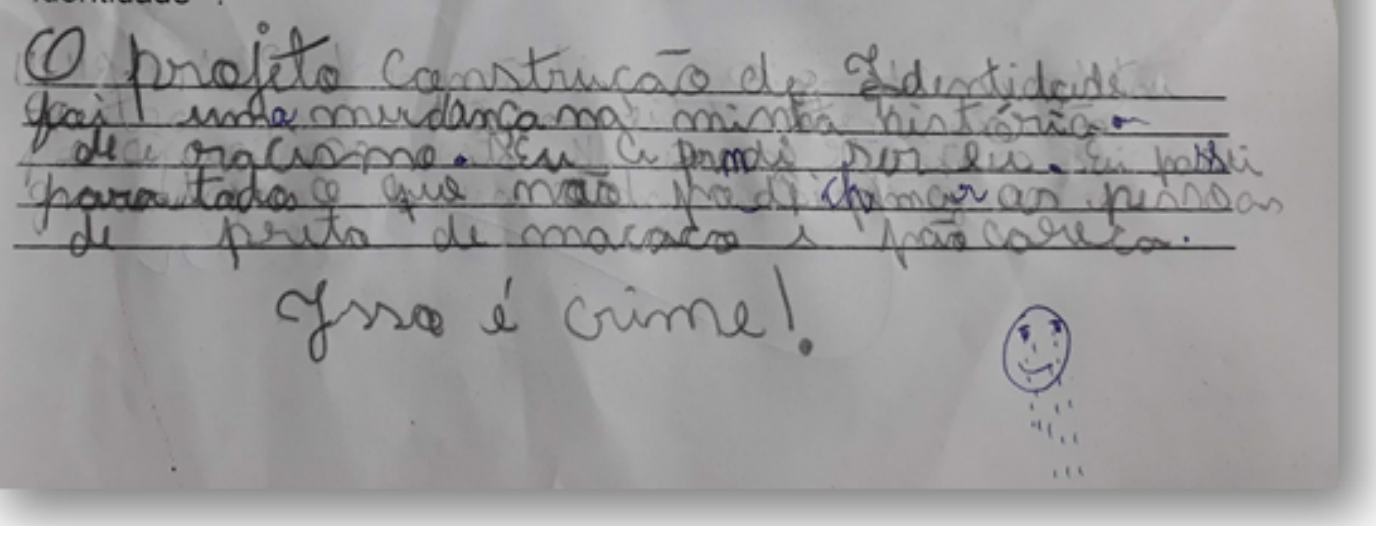

Fonte: Arquivo pessoal das autoras

As ações do projeto, bem como as perspectivas futuras, tornam-se potentes à medida que as parcerias com outros atores e instituições foram sendo construídas, pois desde 


\section{RevistAleph}

o início ficou entendido que a esfera individual é insuficiente. O fortalecimento das redes de apoio será sempre uma tática inteligente dos praticantes do cotidiano.

Assim, uma aproximação com a Universidade foi realizada por meio de um Projeto de Extensão do Curso de Filosofia da Universidade Federal do Rio de Janeiro (UFRJ/IFCS) ${ }^{92}$. 0 grupo Rodas de Filosofia e Transculturalismo teve como objetivo inicial gerar suporte epistêmico e reflexivo para os professores da unidade escolar. Posteriormente, a proposta buscou alcançar o público infantil com oficinas envolvendo os valores afro-brasileiros já mencionados aqui.

Esses movimentos foram e têm sido muito importantes para todos: estudantes, professores, profissionais da escola e comunidade escolar. Importante porque o desejo dos pais e responsáveis estava sendo alcançado - lembra que eles desejaram que as ações do projeto alcançassem toda a escola?

Importante para as crianças que se reconheceram enquanto autoras de histórias reais e também se perceberam lindas nas suas diferentes maneiras de ser e estar no mundo.

Importante para os docentes da escola que estão sendo alcançados com lógicas mais inclusivas da diversidade. E tendo a oportunidade de refletir e dialogar sobre uma educação antirracista em seus percursos formativos ${ }^{93}$.

É importante para a professora que ousou com suas táticas e junto de seus atores, romper com a solidão que muitos docentes enfrentam quando assumem a responsabilidade de lutar contra o racismo estrutural por meio de sua prática educativa.

Na verdade, todos nós ganhamos. Porque os sentidos do fundamento tradicional africano Ubuntu (Eu sou porque nós somos), se fizeram presentes em cada experiência, por meio de uma ética, onde a solidariedade e diálogo foram constantes. Por isso, dedicamos essa escrita às nossas crianças, às crianças pretas e da periferia. A esse momento de resistência e encontros com as táticas dos praticantes da escola Tiradentes, nós dedicamos a todas as crianças que tiveram suas vidas interrompidas pela violência de um Estado genocida. Por isso, bradamos: Vidas Negras Importam! Todas as Vidas Importam!

\footnotetext{
92 Essa aproximação foi por meio dos diálogos que a professora autora realizava com o grupo, visto que este fez parte de seus caminhos de formação enquanto filósofa formada pela UFRJ.

93 Por meio de um projeto institucional junto a Secretaria de Educação de Magé, representado pela COPIED (Departamento Pedagógico I), o grupo Rodas de Filosofia, coordenado pelo professor Fernando Santoro e Marli Azevedo tem ampliado as interações com os docentes, para além das oficinas com as crianças, neste ano de 2020.
} 


\section{Referências}

BERMUTE, K. C. Notas de Campo. Arquivo pessoal. 2019.

BRASIL. Lei no 9.394. Brasília, 20 de dezembro de 1996. Disponível em: https://www.planalto.gov.br/ccivil_03/Leis/L9394.htm .

BRASIL. Lei no 10.639. Brasília, 9 de janeiro de 2003. Disponível em: http://www.planalto.gov.br/ccivil_03/leis/2003/L10.639.htm. Acesso em: 20 de março de 2020.

BRASIL. Diretrizes Curriculares Nacionais para a Educação das Relações Étnico-Raciais e para o Ensino de História e Cultura Afro-Brasileira e Africana. Brasília: MEC/ SEF, 2004.

BITTENCOURT, M. Michel de Certeau 25 anos depois: atualidade de suas contribuições para um olhar sobre a criatividade dos consumidores. Revista Polêmica. v. 11, n. 2 (2012). Disponível em: https://www.e-publicacoes.uerj.br/index.php/polemica/issue/view/245. Acesso em: 20 de março de 2020.

CERTEAU, M. de. A Invenção do cotidiano. Artes de fazer. Petrópolis, Vozes, 1996.

CORSARO, W. The Sociology of childhood. Califórnia: Pine Forge, 1997.

CORSARO, W.A. Entrada no campo, aceitação e natureza da participação nos estudos etnográficos com crianças pequenas. Educação \& Sociedade, Campinas, v. 26, n. 91, p. 443- 464, maio-ago. 2005.

DELGADO, A. C. C.; MULLER, F.. Em busca de metodologias investigativas com crianças e suas culturas. Cadernos de Pesquisa, São Paulo, v. 35, n. 125, p. 161-179, maio/ago. 2005.

EDWARS, C. GANDINI, L. FORMAN, G. As cem linguagens da criança: a abordagem de Reggio Emilia na educação da primeira infância. Porto Alegre: Artmed, 1999.

FANON, F.. Pele negra, máscaras brancas. Tradução de Renato da Silveira. Salvador: 1983.

FREIRE, P.. Educação como prática da liberdade. 23ạ ed. Rio de Janeiro: Paz e Terra, 1999.

FREIRE, P.. Pedagogia da autonomia: saberes necessários à prática educativa. 25. ed. São Paulo: Paz e Terra, 1996.

GONÇALVES, L. A. O.. Reflexão sobre a particularidade cultural na educação das crianças negras. Cadernos de Pesquisa, São Paulo, n. 63, p. 27-29, nov. 1987.

GUERRA, M.. Como provocar o gosto por aprender? Material de divulgação das editoras Ática, Saraiva e Scipione. E-docente: 2019. Disponível em: https://www.edocente.com.br/como-provocaro-gosto-por-aprender-marcia-guerra/. Acessado em: 14/04/2020.

HERNANDEZ, F.. Transgressão e mudança na educação: Projetos de trabalho. Porta Alegre: ArtMed, 1998.

INSTITUTO BRASILEIRO DE GEOGRAFIA E ESTATÍSTICA (IBGE). Dados gerais do município de Magé. 2019. Disponível em: https://cidades.ibge.gov.br/brasil/rj/mage. Acesso em: 29/03/2020. 


\section{RevistAleph}

KOHAN, W.. Entre Deleuze e a Educação: notas para uma política do pensamento. Revista Educação \& Realidade. v. 27, n. 2 (2002) Disponível em: https://www.seer.ufrgs.br/educacaoerealidade/article/view/25922. Acessado em: 14/04/2020.

KRAMER, S.. Autoria e autorização: questões éticas nas pesquisas com crianças. Cadernos de Pesquisa, São Paulo, n. 116, p. 41-59, 2002. Disponível em:

https://www.scielo.br/pdf/cp/n116/14398.pdf. Acessado em: 14/04/2020.

LARROSA, J.. Experiência e alteridade em educação. Revista Reflexão e Ação, Santa Cruz do Sul/SC, v. 19, n. 2, p. 04-27, 2011.

MATURANA, H. e VARELA, F. A árvore do conhecimento: As bases biológicas do entendimento humano. Campinas/SP: Editorial Psy II, 2007.

MOREIRA, R. DOMINICK, R. COARACY, L. CRUZ, L. A Aleph em revista: uma estrada eletrônica. V CEDUCE. 28 a 30 de Junho de 2018. Anais:

http://www.editorarealize.com.br/revistas/ceduce/trabalhos/TRABALHO_EV111_MD1_SA2_ID1329 _03062018175520.pdf. Acesso em 29/03/2020.

NASCIMENTO, A.. Oitenta anos de Abolição. Rio de Janeiro: Cadernos Brasileiros, 1968.

OLIVEIRA, L. F. de.; CANDAU, V. M. F.. Pedagogia decolonial e educação antirracista e intercultural no Brasil. Educ. rev. [online]. 2010, vol.26, n.1, pp.15-40. ISSN 0102-4698. Disponível em: https://doi.org/10.1590/S0102-46982010000100002. Acesso em: 20 de março de 2020.

OLIVEIRA, I.; SGARBI, P. A invenção cotidiana da pesquisa e seus métodos. Educ. Soc., Campinas, vol. 28, n. 98, p. 15-22, jan./abr. 2007. Disponível em:

http://www.scielo.br/pdf/es/v28n98/a02v2898.pdf. Acessado em 12/04/2020.

PEREIRA, S. D.. A Questão Étnico-racial a partir do meu olhar sobre o olhar da criança: promovendo experiências instituintes. Rio de Janeiro: Editora Autografia, 2018.

PEREIRA, S. D.. A Questão Étnico-racial a partir do olhar da criança: a inclusão da diversidade por meio de experiências escolares instituintes. Dissertação de Mestrado: 2016. Disponível em: http://cmpdi.uff.br/2016-2/. Acessado em: 13/04/2020.

PEREIRA, S. D.. A Questão Étnico-racial, perspectivas teóricas críticas e processos educativos em diálogo. Revista Novamerica. № 165 * jan-mar/2020. Disponível em:

http://www.novamerica.org.br/ong/?p=1503. Acessado em 14/04/2020.

SAMPAIO, A. C. J.. Magé na Crise do Escravismo. Sistema Agrário e Evolução Econômica na Produção de Alimentos (1850-1888) Dissertação de Mestrado: 1994. Disponível em:

https://www.historia.uff.br/academico/media/aluno/538/projeto/Dissert-antonio-carlos-juca-desampaio.pdf. Acessado em: 13/05/2020.

SANTOS, B. de S.. Se Deus fosse um ativista dos direitos humanos. Cortez, São Paulo: 2013.

SARMENTO, M. J.. Gerações e alteridade: interrogações a partir da sociologia da infância. Educação \& Sociedade, Campinas, vol. 26, n. 91, p. 361-378, Maio/Ago. 2005. Disponível em:

http://www.cedes.unicamp.br. 


\section{RevistAleph}

SARMENTO, M. J. "O Estudo de Caso Etnográfico em Educação" In N. Zago; M. Pinto de Carvalho; R. A. T. Vilela (Org.) Itinerários de Pesquisa - Perspectivas Qualitativas em Sociologia da Educação (137 - 179). Rio de Janeiro: Lamparina (2a edição), 2011.

TRINDADE, A. L. (org.) Africanidades brasileiras e educação [livro eletrônico]: Salto para o Futuro. Rio de Janeiro: ACERP; Brasília: TV Escola, 2013.

Data do envio: $15 / 04 / 2020$

Data do aceite: 01/07/2020. 